\title{
TOXICOLOGICAL EFFECT OF LONG TERM ADMINISTRATION OF CERTAIN AGRICULTURAL CONTAMINATES ON ALBINO RATS \\ Saleh A.A. ${ }^{1}$; M. M. Kady ${ }^{1}$; I.M. El-Nabarawy ${ }^{2}$ and Sh. E. M. Shalby ${ }^{2}$ 1-Pesticides Dept.,Fac.of Agric., Mansoura Univ., and 2- Pests \& Plant Protection Dept., National Research Centre, Dokki, Cairo, Egypt
}

\begin{abstract}
The objective of this investigation was conducted to study the chronic toxicity of sublethal doses of some very important agriculture chemicals, carbamate nematicide aldicarb ( contains secondary amines), sodium nitrite, sodium nitrate and combination between aldicarb and nitrite or nitrate on some blood content of albino rats. The protective effects of ascorbic acid were studied and the role of sodium chloride to increase the bad effects of previous compounds was also studied.

The obtained data revealed that, rats treated with aldicarb followed by nitrite or nitrate caused significant changes (increase or decrease) more than that in case of treated rats each one alone. Addition of sodium chloride to rats which treated by aldicarb followed by nitrite (nitrate) caused more adverse effects on vital hematological and biochemical parameters. On the contrary, ascorbic acid not prevents the toxic effects of the tested chemicals but playing negligible role of recovery when added to aldicarb followed by nitrite or nitrate treated rats.

Keywords: Aldicarb - N-nitroso compounds - ascorbic acid - sodium chloride hematological effects - secondary amines.
\end{abstract}

\section{INTRODUCTION}

The health hazard of over-exposure to toxic chemicals is dramatized by out break of mass poisoning resulting from exposure to a variety of drugs, food contaminates, pesticides and other environmental pollutants. Also, the contamination of ground livestock and human excrement, other organic waste or chemical fertilizers is a potential hazard throughout the world.

Many agricultural chemicals also contain structures that can be $\mathrm{N}$ nitrosated, human food may contain residues of such compounds and the possibility that they can be $\mathrm{N}$-nitrosated in gastro-intestinal tract or during processing when they are in contact with nitrite should be considered, since nitrite is a common constituent of many food commodities (Eisenbrand et al., 1974).

The formation of carcinogenic $\mathrm{N}$-nitroso compounds by interaction of nitrite with substances susceptible to $\mathrm{N}$-nitrosation has received much attention recently. Substances forming carcinogenic N-nitroso compounds under nitrosating conditions include secondary and tertiary amines (some widely used drugs and pesticides among them), alkylureas and amino acids ( Mirvish, 1970).

Mirvish, (1981) reported that the intragastric formation of $\mathrm{N}$ - nitrose- $\mathrm{N}$ methyl urea from methyl urea and nitrite and of nitrosamines from secondary amines and nitrite was inhibited by adding vitamin $C$ to diet. This inhibition depends on the reduction of nitrite to nitric oxide by ascorbate.

The present study aimed to investigate the toxic effect of the three widely used synthetic chemicals, nematocide aldicarb, sodium nitrate and nitrite on albino rats and the role of ascorbic acid to decrease the toxic effects of these 
compounds. Also the role of sodium chloride was also dealt with on the effects of the tested compounds.

\section{MATERIALS AND METHODS}

The used chemicals:

1-Aldicarb (Temik $15 \%$ G.), insecticide, acaricide, nematicide (Anonymous, 2004).

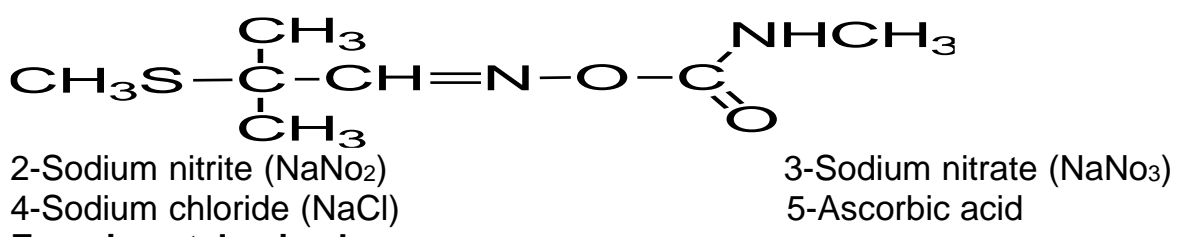

Experimental animals:

Albino rat female's with an average weight of $40-50 \mathrm{gm}$ were provided by the Farm of Experimental Animals at Helwan. The animals were kept under normal laboratory conditions for at least two weeks before initiation of the experiment, and were allowed free access to water and fed on adequate stable diet.

Experimental animals were randomly divided into fourteen groups, each of ten rats and separately caged, and treated weekly during the experimental period (twelve months). Rats of first group were orally administrated by $1 / 10$ $\mathrm{LD}_{50}$ of aldicarb $\left(\mathrm{LD}_{50}=0.9 \mathrm{mg} / \mathrm{kg}\right.$ b.w. Shalby, 1998). The second groups were orally treated by sodium nitrite $(0.42 \mathrm{mg} / \mathrm{kg}$ b.w. Dorsch et al 1984). Rats of the third group were treated by sodium nitrate $(4.2 \mathrm{mg} / \mathrm{kg} \mathrm{b.w}$. Dorsch et al 1984). The fourth group was treated by ascorbic acid $(14.0 \mathrm{mg} / \mathrm{kg}$ b.w. Dorsch et al 1984). The fifth group was treated by sodium chloride $(1.2 \mathrm{mg} / \mathrm{kg}$ b.w. Fukuyama and Suzuki 1959). The sixth and seventh groups was treated by aldicarb followed by nitrite (or nitrate). The eighth and ninth groups was treated by aldicarb followed by ascorbic acid (or sodium chloride). Rats of the tenth and eleventh groups were treated by aldicarb followed by nitrite (or nitrate) and then by ascorbic acid. Rats of the twelfth and thirteenth groups were treated by aldicarb following by nitrite (or nitrate) and then by sodium chloride. The fourteenth group received food and water, and used as control. Toxicants were administrated convenient stomach tube.

At 6 and 12 months, blood samples were collected in two tubes. The heparinzed tube for the hematological effects, while another sample was collected in another clean tube and centrifuged and the serum was separated and kept in $4 \mathrm{C}^{\circ}$ till the biochemical analysis.

I - Hematological study:

Red blood cells (RBCs), White blood cells (WBCs) counts and hemoglobin values $(\mathrm{Hb})$ were determined according Britton, 1963 method.

\section{II - Biochemical analysis:}

The concentrations of creatinine were measured according to the method adopted by Henry et al.(1974), while the activities of GOT and GPT were determined calorimetrically according to Retman and Frankel, (1957) method,. 
All data obtained were statistically analyzed using "F" test at 0.05 and 0.01 levels produce reported by Snedecor and Cochran (1980):

\section{RESULTS AND DISCUSSION}

\section{I- Hematological effects :}

Data obtained in Table (1) indicated that a significant decrease of red blood cells counts was observed in rats treated by aldicarb followed by ascorbic acid after twelve months, it was apparent only after six months. The decrease in RBCs count in rats treated by aldicarb followed by nitrite (31.4 and $42.9 \%$ below the normal level) was more than that in rats treated by aldicarb alone (-15.5 and $-23.0 \%)$, nitrite only (-20.1 and -28.1) at the same periods. There were significant differences in reduction of RBCs counts between treatments of aldicarb followed by nitrite or nitrate beside to sodium chloride $(-39.9$ and $-23.9 \%)$ in one side and those of aldicarb followed by nitrite or nitrate (-31.4 and $-15.5 \%)$ in other side only after six months.

Table (1): Effect of different treatment on red blood cells (RBCs) and white blood cells (WBCs) counts of white albino rat females.

\begin{tabular}{|c|c|c|c|c|c|c|c|c|}
\hline \multirow{3}{*}{ Treatments } & \multicolumn{4}{|c|}{ Red blood cells counts (RBCs) } & \multicolumn{4}{|c|}{ White blood cells counts (WBCs) } \\
\hline & \multicolumn{2}{|c|}{ After 6 months } & \multicolumn{2}{|c|}{ After 12 months } & \multicolumn{2}{|c|}{ After 6 months } & \multicolumn{2}{|c|}{ After 12 months } \\
\hline & $10^{6} / \mathrm{ml}$ & $\%$ & $10^{6} / \mathrm{ml}$ & $\%$ & $10^{3} / \mathrm{ml}$ & $\%$ & $10^{3} / \mathrm{ml}$ & $\%$ \\
\hline 1 & $6.00^{\star *}$ & -15.5 & $5.57^{\star *}$ & -23.0 & $10.07^{\star *}$ & +24.3 & $10.90^{* *}$ & +34.6 \\
\hline 2 & $5.67^{\star \star}$ & -20.1 & $5.20^{\star *}$ & -28.1 & $9.03^{\star \star}$ & +11.5 & $10.20^{* *}$ & +25.9 \\
\hline 3 & $6.20^{\star *}$ & -12.7 & $5.83^{\star *}$ & -19.4 & 8.13 & +0.37 & $9.07^{\star \star}$ & +12.0 \\
\hline 4 & 7.07 & -0.4 & 7.23 & 0.0 & 8.12 & +0.25 & 8.13 & +0.37 \\
\hline 5 & 7.03 & -1.0 & 7.01 & -3.0 & 8.17 & +0.86 & 8.37 & +3.3 \\
\hline 6 & $4.87^{* *}$ & -31.4 & $4.13^{\star *}$ & -42.9 & $12.10^{* *}$ & +49.4 & $12.83^{* *}$ & +58.4 \\
\hline 7 & $6.00^{* *}$ & -15.5 & $5.33^{* *}$ & -26.3 & $11.03^{\star *}$ & +36.2 & $11.87^{* *}$ & +46.5 \\
\hline 8 & 6.90 & -2.8 & $5.87^{\star \star}$ & -18.8 & 8.13 & +0.37 & $9.20^{\star *}$ & +13.6 \\
\hline 9 & $5.73^{\star \star}$ & -19.3 & $5.23^{\star *}$ & -27.7 & $10.07^{* \star}$ & +32.1 & $11.00^{* *}$ & +35.8 \\
\hline 10 & $5.60^{* *}$ & -21.1 & $4.97^{\star *}$ & -31.3 & $10.03^{* *}$ & +23.8 & $11.03^{* *}$ & +36.2 \\
\hline 11 & $6.30^{* *}$ & -11.3 & $5.77^{\star \star}$ & -20.2 & $9.10^{\star \star}$ & +12.3 & $9.83^{\star \star}$ & +21.4 \\
\hline 12 & $4.27^{\star \star}$ & -39.9 & $4.17^{\star *}$ & -42.3 & $15.10^{\star \star}$ & +86.4 & $16.67^{* *}$ & +105.8 \\
\hline 13 & $5.40^{* \star}$ & -23.9 & $5.20^{\star \star}$ & -28.1 & $12.07^{* \star}$ & +49.0 & $13.27^{* *}$ & +63.8 \\
\hline 14 & 7.10 & 0.0 & 7.23 & 0.0 & 8.10 & 0.0 & 8.10 & 0.0 \\
\hline LSD $5 \%$ & \multicolumn{2}{|c|}{0.28} & \multicolumn{2}{|c|}{0.28} & \multicolumn{2}{|c|}{0.23} & \multicolumn{2}{|c|}{0.23} \\
\hline LSD $1 \%$ & \multicolumn{2}{|c|}{0.37} & \multicolumn{2}{|c|}{0.37} & \multicolumn{2}{|c|}{0.30} & \multicolumn{2}{|c|}{0.30} \\
\hline
\end{tabular}

1- Aldicarb 2- Sodium nitrite 3- Sodium nitrate 4- Ascorbic acid 5- Sodium chloride 6Aldicarb + Sodium nitrite 7- Aldicarb + Sodium nitrate 8- Aldicarb + Ascorbic acid 9Aldicarb + Sodium chloride 10- Aldicarb + Sodium nitrite + Ascorbic acid 11Aldicarb + Sodium nitrate + Ascorbic acid 12- Aldicarb + Sodium nitrite + Sodium chloride 13- Aldicarb + Sodium nitrate + Sodium chloride 14- Control.

${ }^{* *}$ Highly significant $\quad$ * Significant

It was found that the decrease in RBCs count in rats treated by aldicarb followed by nitrite or nitrate beside to ascorbic acid (5.60, 4.97 and 6.30,5.77 $X 10^{6}$ ) was of less significantly than that occurred in treated rats by aldicarb followed by nitrite (nitrate) at the same periods. Zidan (1991) obtained similar results. Saleh (1997) found that red blood cells counts were decreased by the administrated of technical and formulation grades of Chlorpyriphos treated rats.

On the contrary, data in the same table showed that WBCs counts increased after twelve months was more than that found after six months. At 
the same time, WBCs counts were highly increased in rats treated by aldicarb with nitrite and also with nitrate $(49.4,58.4$ and 36.2, $46.5 \%$ above normal level) than that found in rats treated by aldicarb alone $(+24.3$ and $+34.6 \%)$ and only by nitrite $(+11.5$ and $+25.9 \%)$ and also nitrite alone $(+0.37$ and $+12.0 \%$ ) after six and twelve months.

Whereas, increasing of WBCs counts in rats treated by aldicarb followed by nitrite or nitrate beside to sodium chloride $(+86.4,+105.8$ and $+49.0,+63.8$ $\%$ ) was significantly more than these occurred in rats treated by aldicarb followed by nitrite or nitrate at the same periods. On the other hand, the increase in WBCs counts in rats, which treated by aldicarb followed by nitrite or nitrate beside to ascorbic acid $\left(10.03,11.30\right.$ and $\left.9.10,9.83 \times 10^{3}\right)$ was less than that in rats, which treated by aldicarb followed by nitrite or nitrate after six and twelve months, respectively. So we can conclude that the increase of WBCs count may be related to the response of toxic agents and other foreign materials in the host environment. The high increase of leucocytes may be due to the inflammatory response induced as defense mechanism. Also, both compounds may affect the leucocytic count by the stressogenic effect of these insecticides on the reticuloendothelial system (Gromysz, 1993). These results are in agreement with those obtained by Zidan (1991), Saleh (1997), and Shalby (2002), who reported that WBCs counts was increased in albino rats, which treated by one-tenth of the $L_{50}$ of pirimiphos-methyl, chlorpyriphos-methyl and fenitrothion.

Data obtained in Table (2) indicated that a high reduction in hemoglobin $(\mathrm{Hb})$ values after twelve months was found than that occurred after six months. The same trend, was found in hemoglobin values in rats, which treated by aldicarb followed by nitrite ( 33.3 and $47.6 \%$ below the normal level) or nitrate, but only after 12 months (-44.7\%) when compared with that recorded in case of rats treated with aldicarb alone (-18.0 and $-39.6 \%)$, nitrite only $(-11.1$ and $-41.1 \%)$ and so nitrate only $(-10.6$ and $-30.7 \%)$ after six and twelve months, respectively.

Whereas, there were no significant reduction in hemoglobin values in treated rats by aldicarb followed by nitrite or nitrate beside to sodium chloride $(-33.9,-53.1$ and $-19.0,-46.4 \%)$ when compared with rats treated by aldicarb followed by nitrite or nitrate treatments at the same periods, except in case of aldicarb followed by nitrate after twelve months. On the other hand, the reduction in hemoglobin values in treated rats by aldicarb followed by nitrite (nitrate) beside to ascorbic acid (-13.1, -27.2 and -6.7, -23.7\%) was less significant than that found in treated rats by aldicarb followed by nitrite or nitrate after six and twelve months, respectively. Reduction in $\mathrm{Hb}$ concentration was due to reduction in total number of RBCs (Seirved, 1972). Black (1983) reported that methemoglobinemia is caused by nitrite that in most instances is produced in the body by microbiological reduction of nitrate.

Methemoglobinemia is condition that may affect human infants, generally in their first few months of life. A few months may be required in infants to develop enough stomach acidity to inhibit the bacterial growth in the stomach and upper small intestine. When infants are affected by diarrhea, the stomach acidity is lessened further. 
Table (2): Effect of different treatment on hemoglobin $(\mathrm{Hb})$ values and creatinine concentration of white albino rat females.

\begin{tabular}{|c|c|c|c|c|c|c|c|c|}
\hline \multirow{3}{*}{ Treatments } & \multicolumn{4}{|c|}{ Hemoglobin $(\mathrm{Hb})$ values } & \multicolumn{4}{|c|}{ Creatinine concentration } \\
\hline & \multicolumn{2}{|c|}{ After 6 months } & \multicolumn{2}{|c|}{ After 12 months } & \multicolumn{2}{|c|}{ After 6 months } & \multicolumn{2}{|c|}{ After 12months } \\
\hline & $(\mathrm{mg} / \mathrm{dl})$ & $\%$ & (mg/dl) & $\%$ & $(\mathrm{mg} / \mathrm{dl})$ & $\%$ & $(\mathrm{mg} / \mathrm{dl})$ & $\%$ \\
\hline 1 & $11.07^{* \star}$ & -18.0 & $8.07^{\star \star}$ & -39.6 & $0.85^{\star \star}$ & +66.7 & $1.85^{\star \star}$ & +249.1 \\
\hline 2 & $12.00^{\star *}$ & -11.1 & $7.87^{\star \star}$ & -41.1 & $0.91^{\star \star}$ & +78.4 & $2.33^{\star \star}$ & +339.6 \\
\hline 3 & $12.07^{\star \star}$ & -10.6 & $9.27^{\star \star}$ & -30.7 & $0.70^{*}$ & +37.3 & $1.73^{\star \star}$ & +226.4 \\
\hline 4 & 13.23 & -2.0 & 13.37 & 0.0 & 0.52 & +2.0 & 0.50 & -5.7 \\
\hline 5 & 13.21 & -2.1 & $13.05^{\star}$ & -2.4 & $0.73^{*}$ & +43.1 & $0.91^{\star *}$ & +71.7 \\
\hline 6 & $9.00^{* *}$ & -33.3 & $7.00^{\star \star}$ & -47.6 & $1.47^{\star \star}$ & +188.2 & $3.36^{\star *}$ & +534.0 \\
\hline 7 & $10.83^{\star \star}$ & -19.8 & $7.40^{\star \star}$ & -44.7 & $1.73^{\star \star}$ & +239.2 & $3.40^{\star *}$ & +541.5 \\
\hline 8 & $12.80^{* *}$ & -5.2 & $9.27^{\star \star}$ & -30.7 & $0.72^{*}$ & +41.2 & $0.90^{* *}$ & +69.8 \\
\hline 9 & $10.90^{\star \star}$ & -19.3 & $7.83^{\star \star}$ & -41.4 & $1.20^{\star \star}$ & +135.3 & $1.73^{\star \star}$ & +226.4 \\
\hline 10 & $11.73^{\star \star}$ & -13.1 & $9.73^{\star \star}$ & -27.2 & $1.14^{\star \star}$ & +123.5 & $2.00^{\star *}$ & +277.4 \\
\hline 11 & $12.60^{* *}$ & -6.7 & $10.2^{\star *}$ & -23.7 & $0.93^{\star *}$ & +82.4 & $1.33^{* *}$ & +150.9 \\
\hline 12 & $8.93^{* *}$ & -33.9 & $6.27^{\star \star}$ & -53.1 & $2.30^{\star *}$ & +351.0 & $3.96^{\star *}$ & +647.2 \\
\hline 13 & $10.93^{\star \star}$ & -19.0 & $7.17^{\star \star}$ & -46.4 & $2.08^{\star \star}$ & +307.8 & $3.90^{\star *}$ & +635.8 \\
\hline 14 & 13.50 & 0.0 & 13.37 & 0.0 & 0.51 & 0.0 & 0.53 & 0.0 \\
\hline LSD $5 \%$ & \multicolumn{2}{|c|}{0.31} & \multicolumn{2}{|c|}{0.31} & \multicolumn{2}{|c|}{0.18} & \multicolumn{2}{|c|}{0.18} \\
\hline LSD $1 \%$ & \multicolumn{2}{|c|}{0.41} & \multicolumn{2}{|c|}{0.41} & \multicolumn{2}{|c|}{0.24} & \multicolumn{2}{|c|}{0.24} \\
\hline
\end{tabular}

1- Aldicarb 2- Sodium nitrite 3- Sodium nitrate 4- Ascorbic acid 5- Sodium chloride 6Aldicarb + Sodium nitrite 7- Aldicarb + Sodium nitrate 8- Aldicarb + Ascorbic acid 9Aldicarb + Sodium chloride 10- Aldicarb + Sodium nitrite + Ascorbic acid 11Aldicarb + Sodium nitrate + Ascorbic acid 12- Aldicarb + Sodium nitrite + Sodium chloride 13- Aldicarb + Sodium nitrate + Sodium chloride 14- Control.

${ }^{* *}$ Highly significant $\quad$ * Significant

Then, bacteria may be active throughout the alimentary tract. If food or drink content of nitrate is in ingested, the bacteria may reduce the nitrate to nitrite, which is absorbed into blood. In the blood, the nitrite is oxidized by the hemoglobin to form nitrate and the hemoglobin is reduced to methemoglobin, which does not carry oxygen to body cells. Death may ensue in severe cases. Similar effects were obtained by Saleh (1997), who found that the amount of hemoglobin was significantly decreased in 15 days old fetuses obtained from treated mothers by $1 / 10$ and $1 / 4$ of the $L D_{50}$ of Gesapax herbicide during the gestation period. On the contrary, Radwan et al (2001), recorded no or slight changes in RBCs counts and hemoglobin content, but a different response occurred with WBCs after fenitrothion, cyphenothrin, azadirachtin and pyriproxyfen treatments.

\section{II -Effects on kidney and liver functions:}

Obtained data in Table (2) showed increases of creatinine concentration in treated rats by aldicarb followed by nitrite or nitrate (1.47, 3.36 and $1.73,3.40 \mathrm{mg} / \mathrm{dl}$ ) was more than that found in rats treated by aldicarb alone $(0.85$ and $1.85 \mathrm{mg} / \mathrm{dl})$, nitrite only $(0.91$ and $2.33 \mathrm{mg} / \mathrm{dl})$ and only by nitrate $(0.70$ and $1.73 \mathrm{mg} / \mathrm{dl})$ after six and twelve months, respectively.

It was found that the increase of creatinine concentration in treated rats by aldicarb followed by nitrite (nitrate) beside to sodium chloride $(2.30,3.96$ and $2.08,3.90 \mathrm{mg} / \mathrm{dl}$ ) was higher than that found in case of treated rats by aldicarb followed by nitrite or nitrate. On the other hand, creatinine concentration were increased in treated rats by aldicarb followed by nitrite (nitrate) beside to 
ascorbic acid $(1.14,2.00$ and $0.93,1.33 \mathrm{mg} / \mathrm{dl})$ and this excesses were lesser than that found in case of treated rats by aldicarb followed by nitrite or nitrate at the same periods. These changes may be due to epithelial necrosis to the renal tubules with nuclear and chromatin changes in the epithelium of cortical tubules (Janssen, 1984). The failure of kidney functions as a result of exposure to pesticides were reported by many investigators; such as ElMaghraby (2004), noticed that significant differences in blood urea and creatinine levels after 3 months of feeding mice on faba and soybean treated with carbaryl. Similar results were obtained by Saleh and Zedan (1995), who noticed that a single dose of the LD50 of pirimiphos-methyl significantly increased creatinine level from $0.61 \mathrm{mg} / \mathrm{dl}$ (control) to $0.72 \mathrm{mg} / \mathrm{dl}$ after one day of treatment Generally, high increasing of creatinine and urea concentrations in $1 / 10 L_{50}$ of lufenuron treated rats more than in case of profenofos may be due to the decreasing role of IGR on glomeular filtration, which subsequently raised the level of serum creatinine uremia. Such finding suggests the induction of renal damage or renal toxicity and probably would lead to renal failure by this compound (Shalby, 2006).

Animals in their living environments, ingest, inhale, and absorb many chemicals that can impose stress on the organism and trigger tissue damage by numerous biochemical mechanisms. Since the liver is a primary site of biotransformation of foreign compounds, it is particularly vulnerable. Data presented in Table (3) showed that a high increase of GOT activity after twelve months was found than that obtained after six months and it was noticed that the increase of GOT activity in rats, which treated by aldicarb followed by nitrite or nitrate $(400.0,440.0$ and $380.0,376.0 \mathrm{u} / \mathrm{ml}$ ) was significantly higher than that found in case of treated by aldicarb alone, and except in treated rats by aldicarb followed by nitrate after twelve months (383.3 and $410.3 \mathrm{u} / \mathrm{ml})$, nitrite $(260.0$ and $310.0 \mathrm{u} / \mathrm{ml})$, and so nitrate $(210.0$ and $243.3 \mathrm{u} / \mathrm{ml}$ ) after six and twelve months, respectively. Data obtained showed that also, an increase in GOT activity in treated rats by aldicarb followed by ascorbic acid $(186.7$ and $280.0 \mathrm{u} / \mathrm{ml}$ ) was found to be less than that found in treated rats by aldicarb only at the same periods. On the other hand, it is clear that a higher increase was happened in GOT activity in treated rats by aldicarb followed by sodium chloride (386.7 and $415.0 \mathrm{u} / \mathrm{ml}$ ) than that found in treated rats by aldicarb alone.

An increase of GOT activity in treated rats by aldicarb followed by nitrite or nitrate beside to sodium chloride $(470.0,510.0$ and $440.0,480.0 \mathrm{u} / \mathrm{ml})$ was found to be higher than that occurred in treated rats by aldicarb followed by nitrite (nitrate) at the same periods. On the other hand, the increase of GOT activity in rats, which treated by aldicarb followed by nitrite or nitrate beside to ascorbic acid $(286.7,316.7$ and $206.7,280.0 \mathrm{u} / \mathrm{ml})$ was found to be lesser than that happened in treated rats by aldicarb followed by nitrite or nitrate.

Data in Table (3) clearly indicated that the glutamic pyruvic transaminase (GPT) activities were going through the same trend as previously mentioned in case of GOT activities in treated rats with different compounds, whereas these activities were increased as compared with those found in control rats, $(82.7$ and $83.3 \mathrm{u} / \mathrm{ml})$. It was noticed that an increase of GPT activity in rats, which treated by aldicarb followed by nitrite or nitrate 
$(311.0,370.0$ and $321.7,425.0 \mathrm{u} / \mathrm{ml})$ was found to be higher than that occurred in treated rats by aldicarb alone $(290.0$ and $350.0 \mathrm{u} / \mathrm{ml})$.

Table (3): Effect of different treatment on GOT and GPT activities of white albino rats.

\begin{tabular}{|c|c|c|c|c|c|c|c|c|}
\hline \multirow{3}{*}{ Treatments } & \multicolumn{4}{|c|}{ GOT activity } & \multicolumn{4}{|c|}{ GPT activity } \\
\hline & \multicolumn{2}{|c|}{ After 6 months } & \multicolumn{2}{|c|}{ After 12 months } & \multicolumn{2}{|c|}{ After 6 months } & \multicolumn{2}{|c|}{ After 12months } \\
\hline & $\mathrm{Ul} / \mathrm{ml})$ & $\%$ & (Ul / ml) & $\%$ & (Ul /ml) & $\%$ & (Ul/ml) & $\%$ \\
\hline 1 & $348.3^{\star \star}$ & +166.5 & $410.0^{* \star}$ & +210.1 & $290.0^{\star \star}$ & +250.7 & $350.0^{\star \star}$ & +320.2 \\
\hline 2 & $260.0^{\star *}$ & +98.9 & $310.0^{* \star}$ & +134.3 & $167.7^{\star \star}$ & +102.8 & $250.0^{\star \star}$ & +200.1 \\
\hline 3 & $210.0^{\star *}$ & +60.7 & $243.3^{\star \star}$ & +83.9 & $147.0^{\star *}$ & +77.8 & $210.0^{* *}$ & +152.1 \\
\hline 4 & 140.0 & +7.1 & 138.7 & +4.8 & 83.0 & +0.36 & 85.3 & +2.4 \\
\hline 5 & $150.0^{*}$ & +14.8 & $170.0^{* *}$ & +28.5 & $105.0^{* *}$ & +27.0 & $115.0^{* *}$ & +38.1 \\
\hline 6 & $400.0^{\star \star}$ & +206.0 & $440.0^{\star *}$ & +232.6 & $321.0^{\star \star}$ & +288.1 & $425.0^{\star *}$ & +410.2 \\
\hline 7 & $380.0^{* *}$ & +190.7 & $376.7^{\star *}$ & +184.7 & $311.7^{\star \star}$ & +276.9 & $370.0^{* *}$ & +344.2 \\
\hline 8 & $186.7^{\star \star}$ & +42.8 & $280.0^{\star \star}$ & +111.6 & $120.0^{\star *}$ & +45.1 & $146.7^{\star \star}$ & +76.1 \\
\hline 9 & $386.7^{* \star}$ & +195.9 & $415.0^{\star \star}$ & +213.7 & $301.7^{\star \star}$ & +264.8 & $410.0^{\star *}$ & +392.2 \\
\hline 10 & $286.7^{* *}$ & +119.4 & $316.7^{* *}$ & +139.4 & $210.0^{* *}$ & +153.9 & $403.3^{* *}$ & +384.2 \\
\hline 11 & $206.0^{* *}$ & +57.6 & $280.0^{* *}$ & +111.6 & $165.0^{* *}$ & +99.5 & $383.3^{* *}$ & +360.1 \\
\hline 12 & $470.0^{* *}$ & +260.0 & $510.0^{* *}$ & +285.5 & $370.0^{\star *}$ & +347.4 & 496.7 & +496.3 \\
\hline 13 & $440.0^{* \star}$ & 236.6 & $480.0^{* \star}$ & +262.8 & $343.3^{\star \star}$ & +315.1 & $430.0^{\star \star}$ & +416.2 \\
\hline 14 & 130.7 & 0.0 & 132.3 & 0.0 & 82.7 & 0.0 & 83.3 & 0.0 \\
\hline LSD $5 \%$ & \multicolumn{2}{|c|}{17.2} & \multicolumn{2}{|c|}{17.2} & \multicolumn{2}{|c|}{16.6} & \multicolumn{2}{|c|}{16.6} \\
\hline LSD $1 \%$ & \multicolumn{2}{|c|}{22.9} & \multicolumn{2}{|c|}{22.9} & \multicolumn{2}{|c|}{22.1} & \multicolumn{2}{|c|}{22.1} \\
\hline
\end{tabular}

1- Aldicarb 2- Sodium nitrite 3- Sodium nitrate 4- Ascorbic acid 5- Sodium chloride 6Aldicarb + Sodium nitrite 7- Aldicarb + Sodium nitrate 8- Aldicarb + Ascorbic acid 9Aldicarb + Sodium chloride 10- Aldicarb + Sodium nitrite + Ascorbic acid 11Aldicarb + Sodium nitrate + Ascorbic acid 12- Aldicarb + Sodium nitrite + Sodium chloride 13- Aldicarb + Sodium nitrate + Sodium chloride 14- Control.

** Highly significant * Significant

On the other hand, an increase in GPT activity in treated rats by aldicarb followed by ascorbic acid $(120.0$ and $146.0 \mathrm{u} / \mathrm{ml})$ was found to be lesser than that found in treated rats by aldicarb only. GPT activity in treated rats by aldicarb followed by sodium chloride $(301.7$ and $410.0 \mathrm{u} / \mathrm{ml}$ ) were highly increased than those happened in treated rats by aldicarb alone or by sodium chloride $(105.0$ and $115.0 \mathrm{u} / \mathrm{ml})$ after six and twelve months for treatment. A higher increase of GPT activity in treated rats by aldicarb followed by nitrite (nitrate) beside to sodium chloride (370.0, 496.7 and $343.3,430.0 \mathrm{u} / \mathrm{ml}$ ) was found to be more than that occurred in treated rats by aldicarb followed by nitrite or nitrate at the same periods.

On the other hand, increasing of GPT activity in rats treated by aldicarb followed by nitrite or nitrate beside to ascorbic acid (210.0, 413.3 and $165.0,383.3 \mathrm{u} / \mathrm{ml}$ ) was found to be lesser than that happened in treated rats by aldicarb followed by nitrite (nitrate). AST and ALT activities were activated in liver of treated animals. The disruption of transaminases from the normal values denote biochemical important and lesions of tissues and cellular function because they are involved in the detoxification process, metabolism and biosynthesis of energetic macromolecules for different essential functions (Tordior and Van Heem Stra-Lequin, 1980). These results are in agreement with those obtained by Kady et. al. (2004), who reported that the combine 
effect of aldicarb and nitrite or nitrate caused severe damaged in liver and kidney tissues. Also, who noticed that addition sodium chloride to aldicarb or aldicarb followed by nitrite (nitrate) caused more pathological effects. The marked increase in serum GPT activity in response to pesticides manifests their potential hepatotoxic actions as hepatic necrosis in accompanied by abnormal increase in serum level of transaminase (El-Garawany et al., 1990). Shalby (2002) reported that significant increase was happened in the activities of transaminases in treated rats by Chlorpyriphos-methyl, pirimiphos-methyl and fentrothion.

Generally, obtained data indicated that, treated animals by aldicarb followed by nitrite or nitrate caused adverse effects on vital biochemical tested parameters more than those occurred in case of aldicarb, nitrite or nitrate alone. Cantor and Blair (1986) reported that under certain conditions bacteria proliferate in the stomach was facilitating conversion of nitrates to nitrites, increasing the nitrite pool and the probability of formation of the mutagenic- carcinogenic nitroso compounds. In addition, some pesticides such as aldicarb, atrazine, carbaryl, carbofuran and simazine have secondary amine structures and react with nitrite at a low $\mathrm{pH}$ level to $\mathrm{N}$-nitroso compounds.

Obtained data also, revealed that addition sodium chloride to aldicarb or aldicarb followed by nitrite (nitrate) caused severe effects on experimental animals. The evidence related to the salt hypothesis proposed by Joossens and Geboers (1981) suggests merely that salt irritates the lining of the stomach and increase the susceptibility of the tissues to whatever carcinogens may be present. The $\mathrm{N}$-nitroso compounds, which are probable but not confirmed human carcinogens, are only one class of carcinogens in the food supplies whose effectiveness generating stomach cancers might be enhanced by a high intake of salt.

On the other hand, data revealed also ascorbic acid (vitamin C) play a negligible role of decreasing the adverse effects of tested chemicals because ascorbic acid caused reduction of nitrite to nitric oxide by the ascorbate. More information is needed about the protective effect of dietary ascorbic acid (vitamin C) for infants receiving nitrate / nitrite from well water or foods such as carrots, spinach, beets and celery. This protective effect may be also important for children and adults, who receive nitrate / nitrite from these or other sources and who may have some adverse effect on growth and development or delayed effects, such as an increased risk of cancer (Johnson, 1988).

\section{REFRANCES}

Anonymous (2004): The Pesticide Manual, version 3.1, 2004-05, Thirteen Ed. Editor: C D S Tomlin.

Black, C. A. (1983): The double - edged sword of nitrogen fertilizer. Counical for Agriculture Science and Technology. Comments from CAST, 1983 -3 .

Britton, C.J. (1963): Disorders of the blood. Textbook. 9th Ed.J. and A. Churchill LTD, London, W.I. 
Cantor, K.P. and A. Blair (1986): Agricultural chemicals, drinking water and public health: An epidemiologic overview. Soil Science Society of America Workshop, Madison Wisconsin. (Unpublished).

Dorsch, M. M.; R.K.R. Scragg; A.J. Michael; P. A. Baghurst and K.F.Dyr (1984): Congenital malformation and maternal drinking water supply in rural South Australia. A case-control study. American Journal of Epidemiology, 119: 473-486.

Eisenbrand, G.; O. Ungerer and R. Prussmann (1974): Rapid formation of carcinogenic $\mathrm{N}$-nitrosamines by interaction of nitrite with fungicides derived from dithiocarbamic acid in Vitro under simulated gastric conditions and in Vivo in the rat stomach. Fd Cosmet. Toxicol. Vol. 12 pp. $229-232$.

El-Garawany, A.A.; H.A. Samaan and M. Sadek (1990): Comparative hepatorenal toxicity of some commonly used chemical environmental pollutants. Egypt J. Pharm. Sci., Vol. 30, No.e-4, pp. 331-336.

El-Maghraby, S. (2004): Toxicological potential to mice of ${ }^{14}$ carbaryl bound residues in faba and soybeans. . Bull. NRC, Egypt, Vol. 29, No. 6, pp. 681-690.

Fukuyama, S.T. and T. Suzuki (1959): Studies of the causation of gastric cancer. 2- the relation between gastric cancer mortality rate and salted food in take in several places in Japan. Bull. Inst. Publ. Health (Japan), 8:187-198.

Gromysz (1993): Substrate specificity of mouse-liver microsomal enzymes in S-fenvalerate metabolism ACS Symposium series No. 42, synthetic Senvalerate. American Chemical Society, Washington, D.C.

Henry, R.J.; Cannon, D.C. and Winkelman, J.W. (1974): Clin. Chem., Principles and Techniques, Harper' and Row, Publ., pp. 415.

Janssen, W. (1984): Forensic Histopathology. Spring- Verlag, Berlin, NY, pp. 314-315.

Johnson, C.D. (1988): The continuing of nitrate contamination of ground water and wells in rural areas. The University of lowa, lowa city, lowa 52242 (319: 335-442).

Joossens, J.V. and J. Geboers (1981): Nutrition and gastric cancer. Proceeding of the Nutrition Society, 40:37-46.

Kady, M. M.; A.A. Saleh; I. M. El-Nabarawy and Sh. E.M. Shalby (2004): The effects of some contaminants on white albino rat females 2-The histopathological effects on liver and kidney tissues. The meeting of the Egyptian Soc. Toxicol., Bibliotheca Alex. Feb. 18 - 19 , 2004. Abst., pp. 29.

Mirvish, S. S. (1970): Kinetics of dimethylamine nitrosation in relation to nitrosamine carcinogenesis. J. Nat. Cancer Inst. 44, 633.

Mirvish, S. S. (1981): Inhibition of the formation of carcinogenic N-nitroso compound by ascorbic acid and other compounds. New York, Grune, $127-168$.

Radwan, M.U.; Z.A. Hindy; M. Abdel-Megeed and A. Zrook (2001): Residual activity of orally administrated pesticides used on fruits and vegetables on rat blood parameters behavior. Annals Agric. Sci., Ain Shams Univ., Cairo, Egypt, 46(1): 365-382. 
Reitman, S. and Frankel, S. (1957): A colourimetric method for determination of serum glutamic oxaloacetic and glutamic pyruvate transaminases. Amer. J. Clin. Path., 28: 26-33.

Saleh, A.A. (1997): Experimental studies on the effect of Gesapax herbicide on the mothers and their fetuses. J. Agric. Sci. Mansoura Univ., 22 (7):2451 - 2467

Saleh, A.A. and H.A.Zedan (1995): Acute and subchronic toxicity of pirimiphos-methyl for white rat. $1^{\text {st }}$ Int. Conf. of pest control. Mansoura, Egypt, 1995, pp. 429-443.

Saleh Amal, Y.(1997): Toxicological influence of technical and formulated Chlorpyriphos on blood fractions respiratory cytochrome -C-system and growth rate of male albino rats. J. Agric. Sci. Mansoura Univ., 22 (7): 2483-2494.

Seirverd, C.E. (1972): Hematology for medical technology, $4^{\text {th }}$ Ed. Lee and Febiger Philadelphia, 300-363.

Shalby, Sh. E. M.(1998): Toxicological studies on experimental rats. M. Sci. Thesis, Fac., Agric., Mansoura Univ.

Shalby, Sh. E. M. (2002): Determination of pesticide residues in and on tomato fruits and their effects on experimental rats. Ph.D. Thesis, Fac. Of Agric., Mansoura Univ.

Shalby, Sh. E M. (2006): Comparative hematological and hepatorenal toxicity of IGR, Lufenuron and Profenofos insecticide on albino rats. J. Egypt. Soc. Toxicol. Vol. 34: 85 - 98 (Jan. 2006).

Snedecor, G.W. and W.G. Cochran (1980): Statistical Methods. $7^{\text {th }}$ (Ed). State university press, Ames, lowa.

Tordior, W.F. and E.A. Van Heem Stra-Lequin (1980): Field studies monitoring exposure and effects in the deffelopment of pesticides. Elsevier, Amsterdam, Oxford, New York: 207.

Zidan, A.A. (1991): Biochemical and hematological changes in blood of male mice as affected by Sumicidin and Sumithion. Fourth Arab Congress of plant protection, Cairo, 1-5 Dec., 1991, pp. 196 -202.

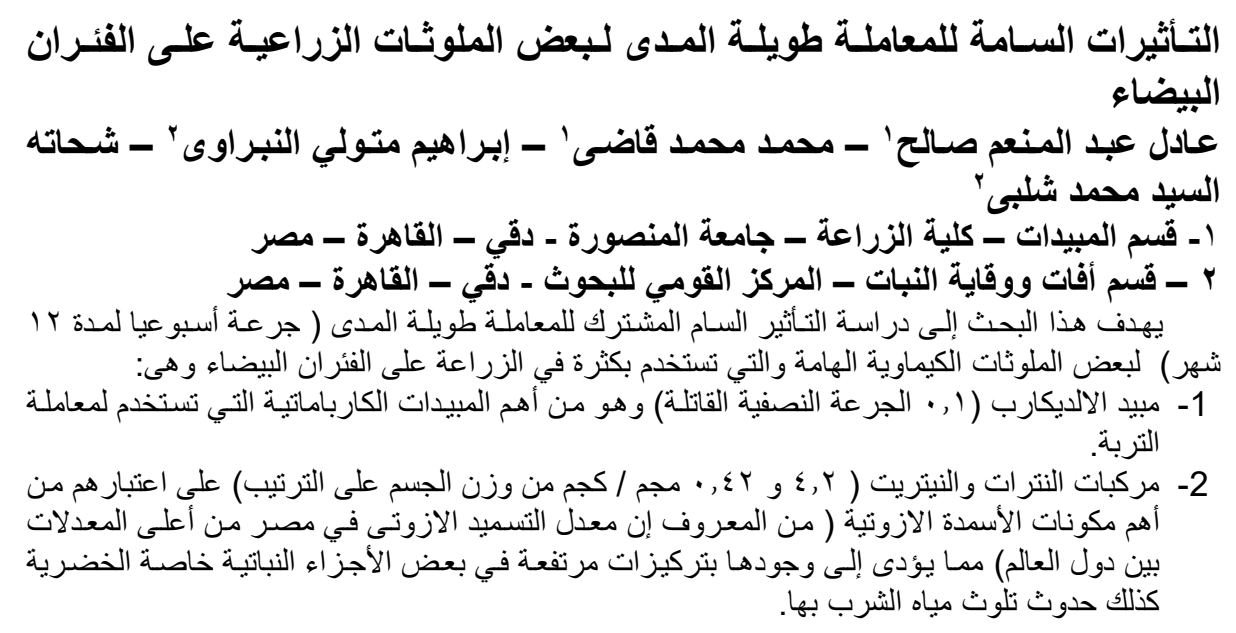




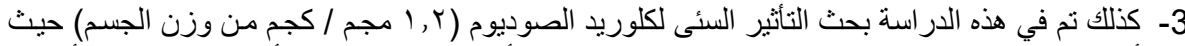

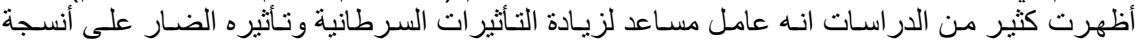

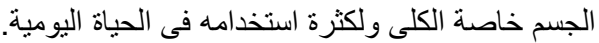

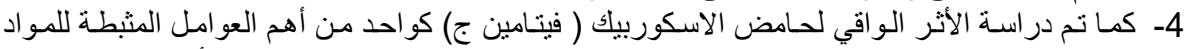

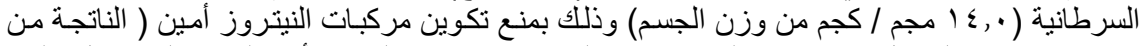

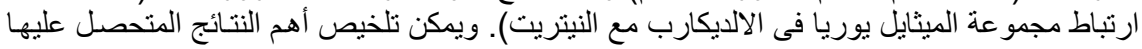

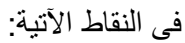

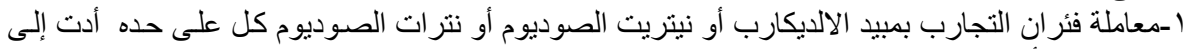

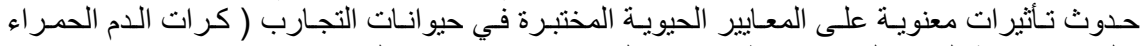

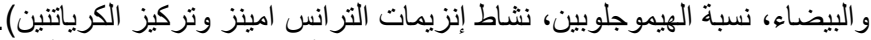

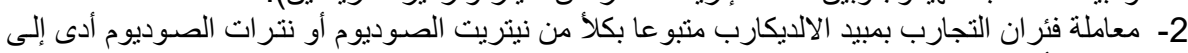

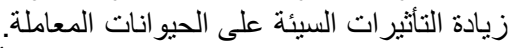

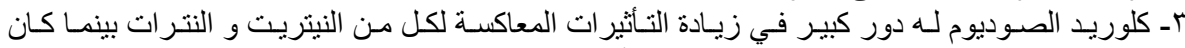
لحامض الاسكوربيك دور ضعيف في خفض التأثيرات الغير مر غوبة للمركبات المختبرة على المئ الحيو انـات

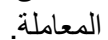

